\title{
Renewable energy in Iran: Challenges and opportunities for sustainable development
}

\author{
${ }^{*} \boldsymbol{F}$. Atabi \\ Department of Environmental Engineering, Graduate School of the Environment and Energy,
}

Islamic Azad University, Science and Research Campus, Tehran, Iran

\begin{abstract}
Around the globe, developing countries have reported different cases of successfully implemented Renewable Energy (RE) program supported by bilateral or multilateral funding. In developing countries subsidy has played a big role in RE program marketing and whether this will lead to sustainable development is yet to be determined. The adoption of implementation strategies that will support sustainable development and overcoming barriers that hinder expansion of Renewable Energy Technologies (RETs) still remains as a big challenge to stakeholders involved in promotion of RE resources in developing countries. In this respect, developing countries need to re-examine their environmental policy for promotion of RETs in order to define its role in revitalization of their economies. This paper reviews the policy incentives for promotion of RETs in the Islamic Republic of Iran. Setting-up international collaborative business ventures between local industry in Iran and RE companies in developed countries is proposed as an implementation strategy that will appropriate diffusion of RETs in the country. An organizational framework that may help to attain this objective is discussed and a structural model for RE business partnership is presented. It is concluded that with appropriate policy formulations and strategies, RETs can bring about the required socio-economic development in Iran.
\end{abstract}

Key words: Sustainable development, RET, energy system, international collaboration, CDM

*E-mail:far-atabi@jamejam.net

\section{Introduction}

In developed and developing countries, development of renewable energy technology (RET) is viewed both as a process of diversification of energy sources and as a creation of an alternative energy option that will help curb down global climate change and create energy security for the future. Furthermore, this would increase energy supply alternatives for sustainable development and finding a way for better use of fossil fuel resources (Table 1).

Due to various financial and technical constrains, RE remains untapped in I.R.I. Iran continues to be heavily dependent on fossil fuels. The detrimental impacts on the environment, and the financial burden placed on the economy, through the current inefficient use of these fuels, need to be addressed through the application of appropriate technologies, national energy policies and management measures. Nonetheless, the social and economic development and poverty alleviation are the overriding priorities of the Islamic Republic of Iran. The energy requirements for the urgently needed socioeconomic development in this country could be provided by RE sources. Thus, in order to promote RETs in Iran more effective and responsive policies are required that would cater for immediate needs of people.

\section{General features of energy economy in Iran}

The Islamic Republic of Iran is situated in the southwestern part of Asia and the far eastern part of the Middle East. The Caspian Sea is in the north and in the south, the Persian Gulf and the sea of Oman, connects the country to the Indian Ocean and international waterways. Iran has a total territorial area of $1,648,000$ square kilometers and population of around 63.86 million in the year 2000 (Table 2 ). The share of Iran primary energy import and export in the year 2000 are shown in Figures1 and 2.

\section{Crude oil}

Iran is rich in energy resources. Its proven oil reserves are 89.7 billion barrels with reserves to production ratio of $72.7 \%$ in 1999 . 
Total refining capacity in 1999, produced by 9 per day (IIES, 2001), (Figures 3 and 4).

\section{Natural gas}

Iran's proven natural gas reserves are estimated at around 26.6 trillion $\mathrm{m}^{3}$, which ranks Iran second in the world $(17 \%$ of total world reserves in 2000), (Table 3). 4 main gasprocessing plants handle production of gas. During the past decade there has been an increase in the share of natural gas in total energy production, i.e., from 4.2 percent in 1982 refineries, was more than 1.35 million barrels to 21.6 percent in 1999 . While the oil shares in total energy production dropped from 94.1 percent to 77.4 percent during the same period. The average domestic consumption of natural gas in the year 2000 was about 170 million $\mathrm{m}^{3} /$ day. In the $21^{\text {st }}$ century, natural gas will play a very important role in the Iranian gas export policy.

Table 1: Liquid hydrocarbon reserves of Iran (Billion Barrel) (IIES, 2001)

\begin{tabular}{|cccccc|}
\hline \multicolumn{2}{|c}{ Location } & \multicolumn{5}{c|}{ Reserve } & $\begin{array}{c}\text { Cumulative Production up to } \\
2000\end{array}$ \\
\hline Onshore & & Primary & Secondary & Total & \\
\hline \multirow{2}{*}{$\mathrm{z}$} & Oil & 93.56 & 20.44 & 114 & 48.4 \\
\cline { 2 - 6 } & Condensate & 5.98 & - & 5.98 & 0.95 \\
\hline Offshore & Total & 99.54 & 20.44 & 119.98 & 49.35 \\
\hline & Oil & 11.10 & 6.60 & 17.70 & 4.60 \\
\hline & Condensate & 15.80 & - & 15.80 & 0.01 \\
\hline Total & 26.90 & 6.60 & 33.50 & 4.60 \\
\hline
\end{tabular}

Table 2: Iran sectorial energy consumption (mmBoe) (IIES, 2001)

\begin{tabular}{|c|c|c|c|c|c|c|c|c|}
\hline Description/Year & 1976 & 1981 & 1986 & 1991 & 1996 & 1998 & 1999 & 2000 \\
\hline \multicolumn{9}{|l|}{ Final Energy Consumption } \\
\hline \multicolumn{9}{|l|}{ Oil Products } \\
\hline Residential/Commercial & 43.24841 & 52.72497 & 70.04162 & 83.50963 & 113.8544 & 108.1782 & 119.6104 & 124.3984 \\
\hline Industry & 29.23473 & 44.07177 & 60.31704 & 69.61647 & 53.41498 & 55.5564 & 57.876 & 60.19104 \\
\hline Transportation & 45.4054 & 53.25046 & 80.38169 & 102.4055 & 145.6473 & 159.2724 & 154.336 & 160.5094 \\
\hline Agriculture & 9.56403 & 13.48778 & 23.09281 & 29.11234 & 28.93921 & 28.8234 & 19.292 & 20.06368 \\
\hline Others & 80.20743 & 11.63102 & 12.35884 & 16.72604 & 24.00015 & 50.1696 & 34.7256 & 36.11462 \\
\hline Total Oil Products & 207.660 & 175.166 & 246.192 & 301.37 & 365.856 & 402 & 385.84 & 401.2772 \\
\hline \multicolumn{9}{|c|}{ Natural Gas } \\
\hline Residential/Commercial & 0.488147 & 9.488424 & 21.25735 & 28.63733 & 77.4822 & 90.9818 & 103.88 & 121.9 \\
\hline Industry & 6.745903 & 5.559552 & 7.591288 & 41.33922 & 79.73469 & 78.5694 & 84.28 & 98.9 \\
\hline Others & 9.091949 & 0.192024 & 0.203364 & 22.94145 & 12.14311 & 12.4488 & 7.84 & 9.2 \\
\hline Total Natural Gas & 16.326 & 15.24 & 29.052 & 92.918 & 169.36 & 182 & 196 & 230 \\
\hline \multicolumn{9}{|c|}{ Solid Fuel } \\
\hline Residential/ Commercial & 3.405918 & 3.371722 & 3.506454 & 3.00487 & 2.134526 & 2.85798 & 2.88 & 3.12 \\
\hline Industry & 8.416082 & 6.757018 & 6.314564 & 5.75313 & 7.541474 & 8.04202 & 9.12 & 9.88 \\
\hline Total Solid Fuel & 11.822 & 10.1288 & 9.8211 & 8.758 & 9.676 & 10.9 & 12 & 13 \\
\hline \multicolumn{9}{|c|}{ Electricity } \\
\hline Residential/ Commercial & 3.429765 & 6.568967 & 12.95073 & 19.26443 & 22.81584 & 26.25074 & 28.08 & 32.94 \\
\hline Industry & 4.997608 & 5.099065 & 6.622415 & 8.84662 & 16.57481 & 17.35928 & 18.2 & 21.35 \\
\hline Agriculture & 0.195765 & 0.489967 & 1.284853 & 2.262135 & 3.39735 & 4.024504 & 4.056 & 4.758 \\
\hline Others & 0 & 0 & 0 & 1.17997 & 1.661025 & 0.0305 & 1.664 & 1.952 \\
\hline Total Electricity & 8.6232 & 12.158 & 20.858 & 31.5532 & 44.4491 & 47.6651 & 52 & 61 \\
\hline Total Energy Consumption & 244.4312 & 212.6928 & 305.9231 & 434.5992 & 589.3411 & 642.5651 & 645.84 & 705.2772 \\
\hline
\end{tabular}




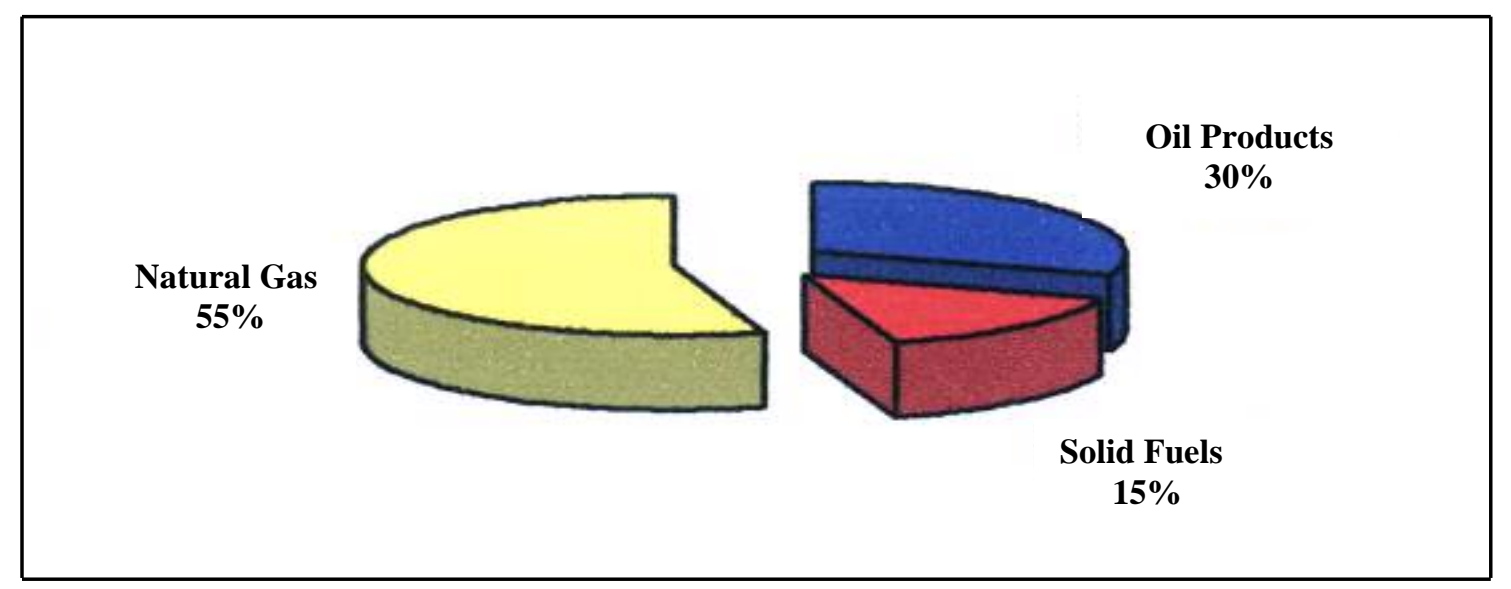

Figure 1: Share of Iran primary energy import in 1999 (IIES, 2001)

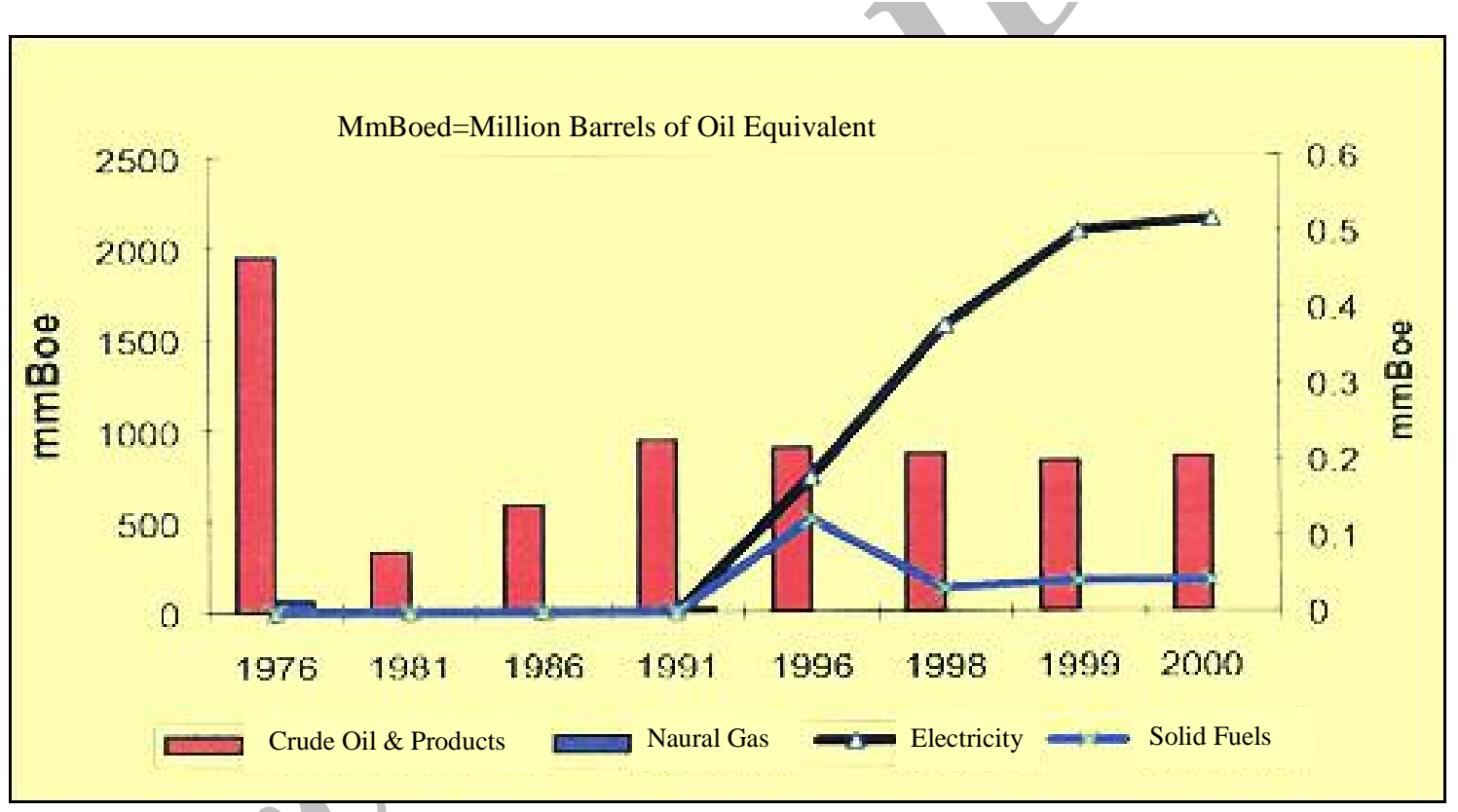

Figure 2: Iran primary energy export (IIES, 2001)

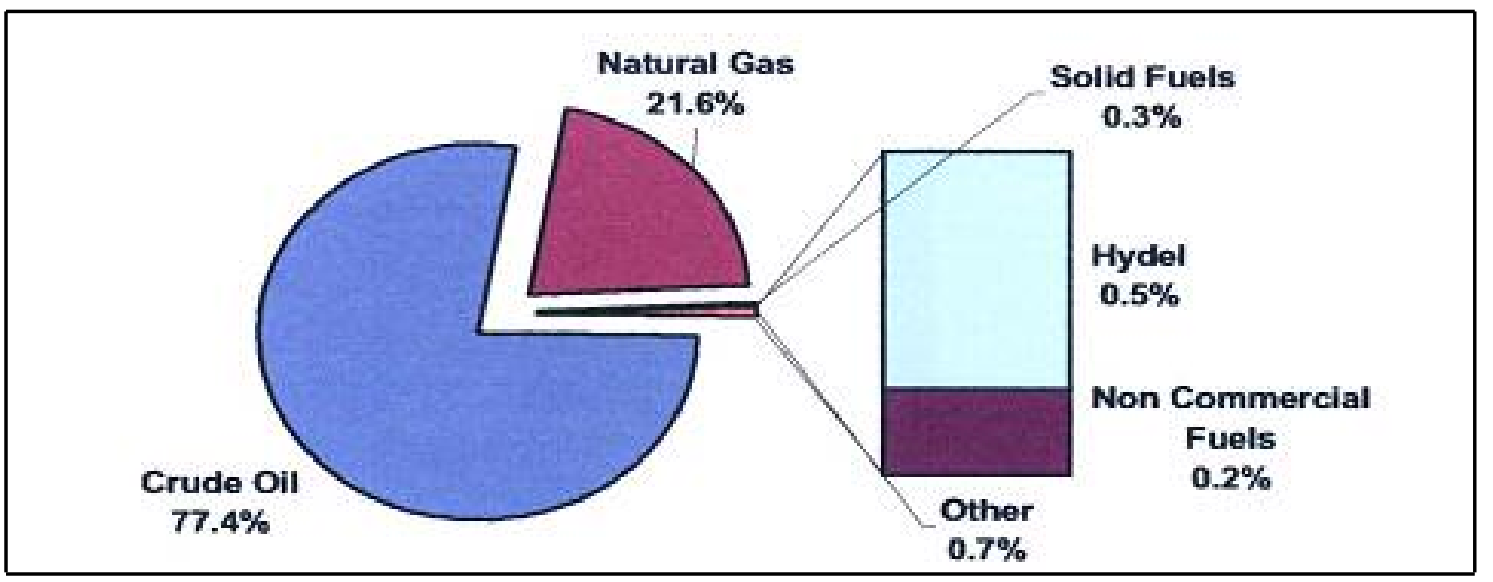

Figure 3: Share of Iran primary energy production in 1999 (IIES, 2001) 


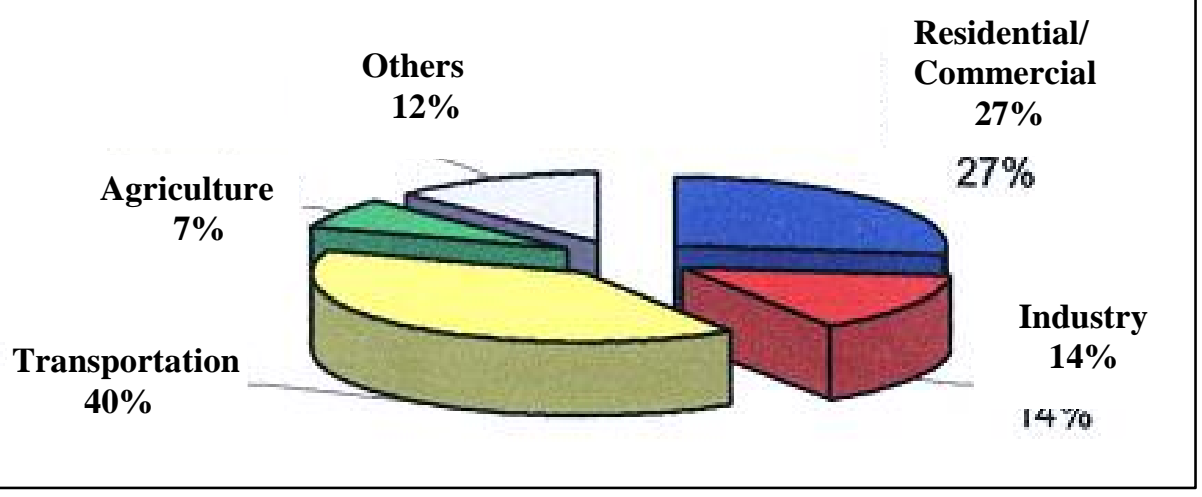

Figure 4: Share of oil products consumption in each economic sector in 1999 (IIES, 2001)

The prospective markets for Iranian natural gas via pipeline are Turkey, Armenia, Pakistan, India and via LNG for eastern countries (IIES, 2001), (Figures 5 and 6).

\section{Coal}

Iran has insignificant coal reserves and its share in the supply of primary energy production is $1 \%$. Its proven coal reserves are estimated at around 13 billion tones in 1999 of which, includes 7 billion tones of thermal coal and 6 billion tones of coking coal (IIES, 2001),
(Figures 7 and 8).

\section{Power generation}

From 1980-1990, Iran's total energy consumption soared from 207 million barrels oil equivalent (mmBoe) in 1980 to 646.1 mmBoe in 1999 (more than $200 \%$ increase). In 1999 total electric power capacity in Iran was 23,293 MWe, of which $41 \%$ was fossil steam, $31 \%$ gas turbine, $7 \%$ hydropower and $21 \%$ was diesel fuelled (Figure 9).

Table 3: Iran total electricity supply (IIES, 2001)

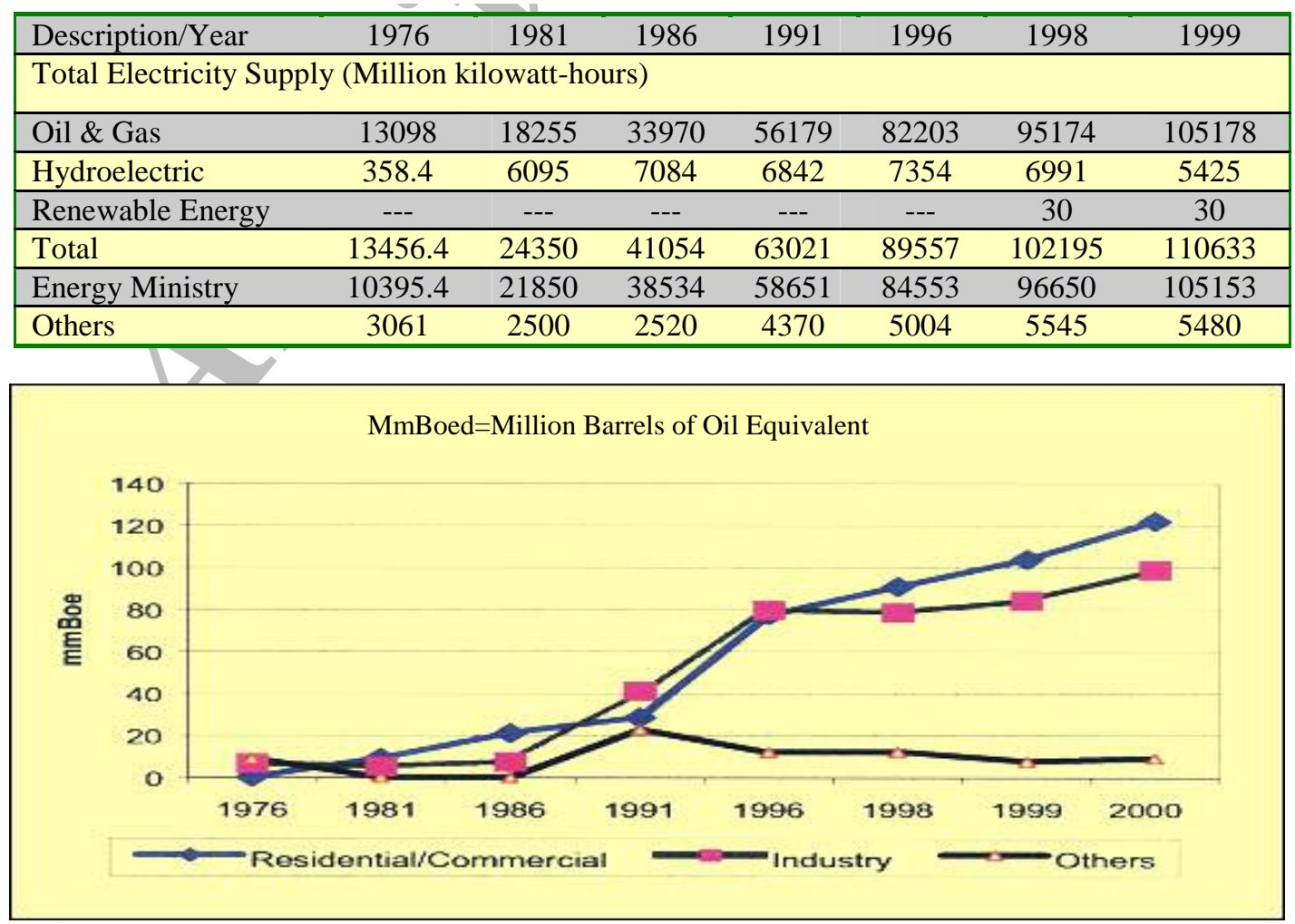

Figure 5: Natural gas consumption (IIES, 2001) 


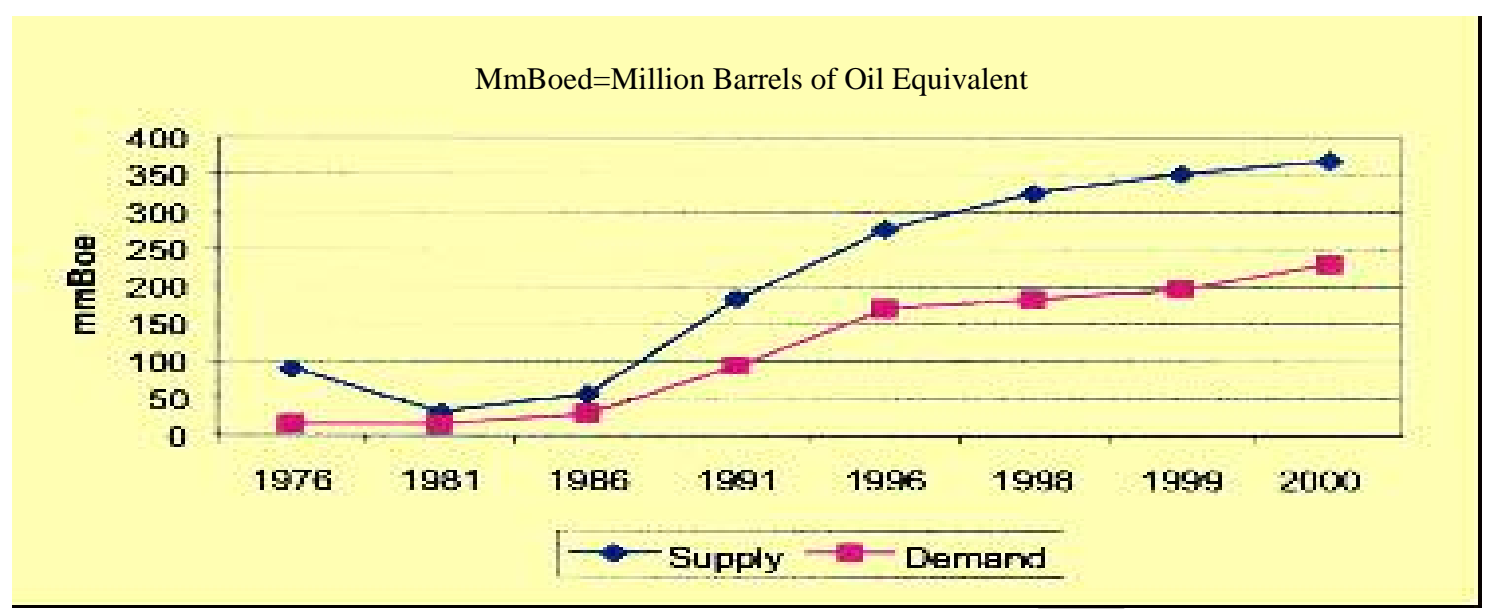

Figure 6: Natural gas supply and demand (IIES, 2001)

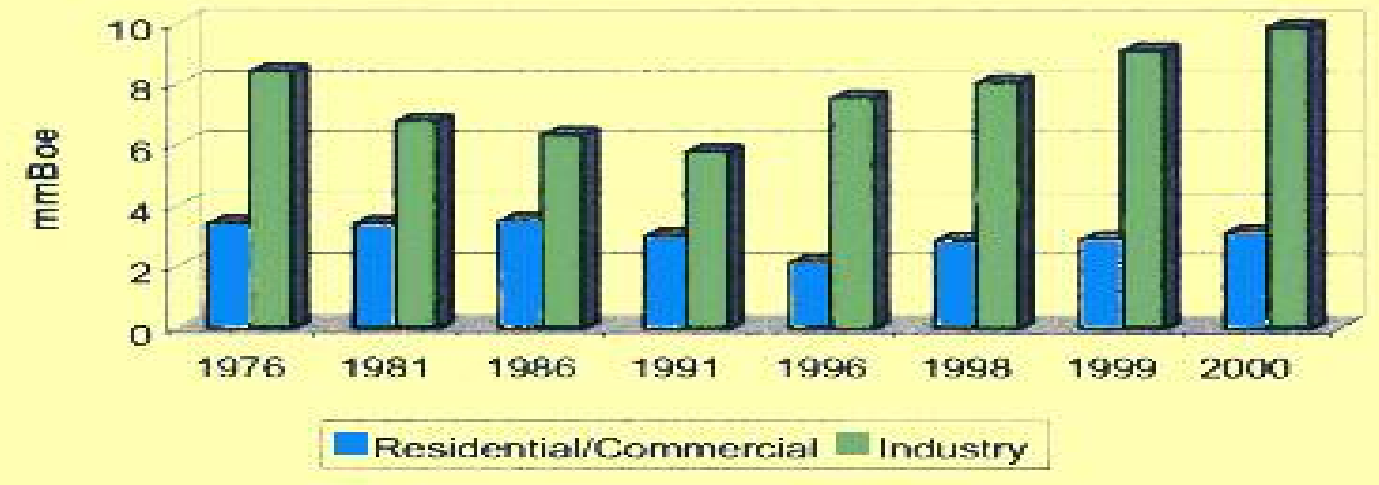

Figure 7: Iran sectorial coal consumption (IIES, 2001)

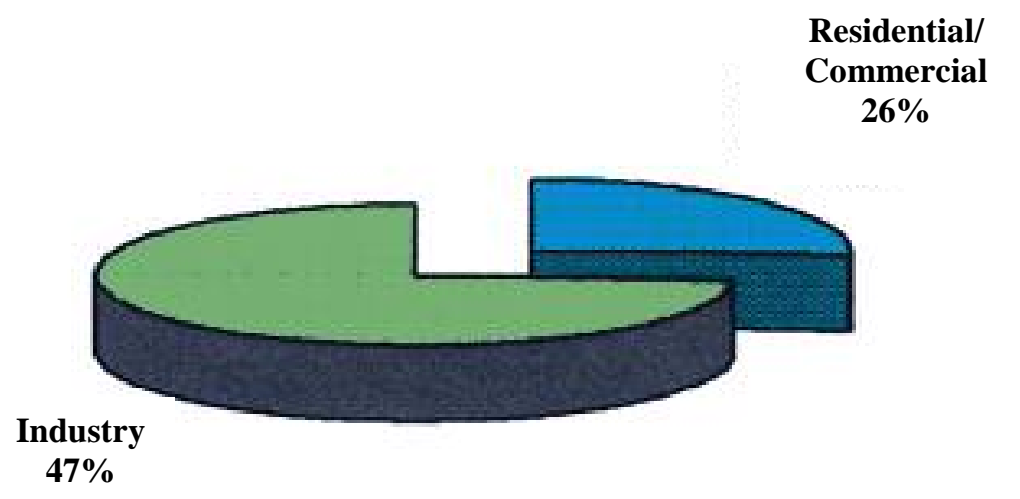

Figure 8: Share of coal consumption in each Iran economic sector in 1999 


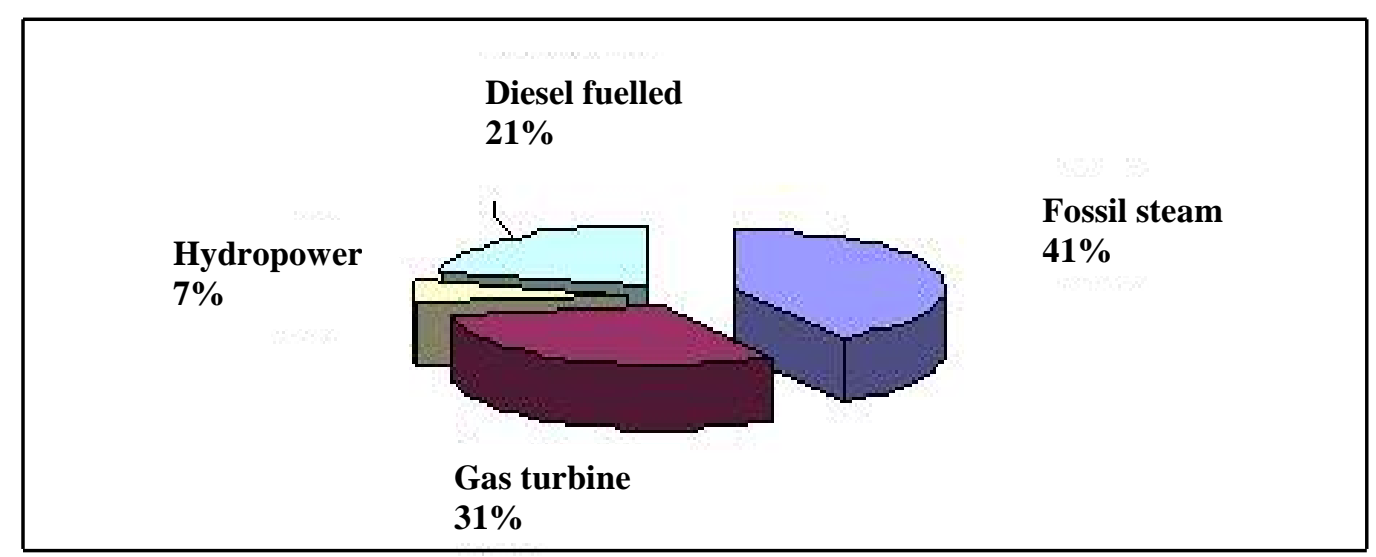

Figure 9: Share of kind of power generation in 1999 (IIES, 2001)

The present installed electric power capacity is about $35,195 \mathrm{MW}$ in 2002 . By the end of the Third Five-Year National Development Plan, the efficiency of fuel consuming generators is to be improved from $33.8 \%$ to $36 \%$. Presently, electric energy is available to $100 \%$ of the Iranian urban and 95\% of the rural population (CRED, 2002), (Table 4).

Table 4: Gas reserves of Iran (TCM) (IIES, 2001)

\begin{tabular}{|cccc|}
\hline $\begin{array}{l}\text { Location } \\
\text { of Fields }\end{array}$ & $\begin{array}{c}\text { Total } \\
\text { Reserves }\end{array}$ & $\begin{array}{c}\text { Cumulative } \\
\text { Production } \\
\text { (End 2000) }\end{array}$ & $\begin{array}{c}\text { Remaining } \\
\text { Reserves } \\
\text { (End 2000) }\end{array}$ \\
\hline Onshore & 14.43 & 1.67 & 12.76 \\
\hline Offshore & 13.96 & 0.12 & 13.84 \\
\hline Total & 28.39 & 1.79 & 26.60 \\
\hline
\end{tabular}

\section{Hydro power}

Iran has installed power generation capacity of about $31 \mathrm{GW}$ of which around $93 \%$ is thermal (natural gas or oil) and about $7 \%$ Is hydroelectric. The total potential of hydropower 20000 MW even though some published reports indicates potential capacity as high as 42000 MW (IIES, 2001). During the Second Five-Year National Development Plan, the total nominal hydro electrical power generation consisted of $2500 \mathrm{MW}$. The share of hydroelectric energy at the end of $4^{\text {th }}$ FiveYear National Development Plan (2009) is expected to be 8700 MW. Comparison between hydropower shares in various years reveals an increase from 6\% in 1996 to about $13 \%$ in 2002. Karoon in Khuzestan Province in southern Iran is the main river for the future Iranian hydroelectric development. In early 1990's the government policy makers turned their attention towards the development of hydroelectric power. In March 1990, seven dams became operational with various capacities for generation of electricity (Table 5).However there are some obstacles for development of hydroelectric power plants, where the most prominent is the lack of financial resources.

\section{Renewable energy}

Iran's renewable energy consumption is negligible. With $9 \%$ of the world's oil reserves and $17 \%$ of its natural gas reserves, Iran has an abundant supply of fossil fuel resources, which tends to discourage the pursuit of alternative renewable energy sources.

\section{Wind energy}

According to the research and studies which have been carried out and the present wind turbine technology in the country, it has been estimated that the wind energy potential in Iran is more than $15000 \mathrm{MW}$ for electricity production. Since Iran has many windy regions, utilization of this type of energy would not only be possible but also economically feasible (Ministry of Energy, 1998). Presently, some of the operated wind energy projects in Iran are as follow:

- In the site called Manjil, situated in the NW part of the country, a 10.1 MW Wind Farm with 300 and $500 \mathrm{~kW}$ turbines with an aid of the GEF/World Bank has been installed (1995), where average wind speed is more than $11 \mathrm{~m} / \mathrm{sec}$ at hub height. 
- In Manjil, another 90MW Wind Farm equipped with the $660 \mathrm{~kW}$ turbines is under construction.

- The eastern parts of Iran have some areas with the average wind speed of about $8-10 \mathrm{~m} / \mathrm{sec}$ at $40 \mathrm{~m}$ heights. The local utility is constructing a 23 MW Wind Farm, which will be completed by the end of 2003 . In the $3^{\text {rd }}$ Five-Year National Development Plan, it is planned to install a $250 \mathrm{MW}$ Wind Farm.

- A 1000 MW Wind Farm is planned by the end of the $4^{\text {th }}$ Five-Year National Development Plans

Assuming the fixed cost of fuel and foreign exchange rates in the future, the cost of electricity produced by wind turbines in Iran, is estimated to be $4-5$ cents $/ \mathrm{kWh}$. The cost of electricity for steam and gas power plants is about 2 and 2.5 cents/kWh respectively plus the social costs of the three major air pollutants $\left(\mathrm{CO}_{2}, \mathrm{SO}_{2}\right.$ and $\left.\mathrm{NO}_{2}\right)$, which ranges from 3 to 4 cents/kWh (2002). Comparing this total east to the price of electricity generated by wind power plants, could easily demonstrate the cost advantage of wind power plants (CRED, 2002).

\section{Solar energy}

Iran has an average solar insulation of $2000 \mathrm{kWh} / \mathrm{m}^{2}$.yr. The sunny hours which sunshine could be utilized are about 2800 $\mathrm{hr} / \mathrm{yr}$. Solar energy has not been formally commercialized yet. Regions having high potential for solar energy are: Shiraz, Tehran, Khorasan, Yazd, and Semnan (IAEA, 2000).

Some of the completed solar energy projects are:

- $10 \mathrm{~kW}$ Photovoltaic Power Plant at "Dorbeed" village in Yazd Province.

- 2 Photovoltaic Power Plant at "Hosseinian" and "Moalleman" village in Semnan Province with the total capacity of $92 \mathrm{~kW}$.

- $250 \mathrm{~kW}$ Solar Power Generator in Shiraz.

- 350 units $\left(1400 \mathrm{~m}^{2}\right)$ Solar Water Heaters.

- P.V. pumping for agricultural use, P.V. electricity generation for a border post and P.V. street lighting

- Some of the ongoing solar energy projects are:

- 1MW Solar Power Thermal Plant under construction in Talegan-Karaj.

- $45 \mathrm{~kW}$ grid connected P.V. under constructed in Talegan
- 650 units $\left(2600 \mathrm{~m}^{2}\right)$ Solar Water Heaters for domestic use under construction.

- 2 units $\left(400 \mathrm{~m}^{2)}\right.$ Solar Water Heater for village public baths under construction.

\section{Geothermal energy}

Iran has high geothermal energy potential and the main regions for geothermal energy generation are Sabalan, Makoo, Khoy (Azerbaijan Province) and Damavand (Tehran Province). The total potential of geothermal energy is approximately 60 billion Giga Jules (Ministry of Energy, 1998).

As for geothermal projects, some studies have been conducted to design a prototype Geothermal Power Plant for producing electricity. One of the ongoing related projects is a 100 MW Geothermal Power Plant at exploring stage in Sabalan.

\section{Nuclear energy}

Prior to the revolution, certain activities in the nuclear energy research were carried out. The first phase of the Bushehr Nuclear Power Plant for 1000 MW nominal powers and $915 \mathrm{MW}$ of net produced power was established in 1974 and stopped in 1978 due to political turmoil. The project activity was restarted in 1999 and is expected to be completed by 2004 .

\section{Other renewable energies}

Based on several investigations and researches conducted during recent years, it is not expected any considerable potential for Wave, Ocean Thermal and Tidal Energy in Iran.

\section{Substitution of fossil fuels}

Energy technology has to continuously redefine it in order to adapt to the new and emerging situations and circumstances. Renewable technologies are of no exceptions. It is time to think about the likely scenarios in the Five-Year National Development Plan of Iran and how renewable energy can establish itself in the changing environment. First we need to ask what are the criteria that determine choices of the energy technology. Moreover, as we review this progress during last decades, the renewable sources have not captured even $1 \%$ of energy market in Iran (Figure 10). New contexts have emerged recently, as outlined below: 
Table 5: Iran electricity potential forecast in the third five-year national development plan (MW) (IIES, 2001)

\begin{tabular}{|lcccccc|}
\hline \multicolumn{1}{|c}{ Index } & 2000 & 2001 & 2002 & 2003 & 2004 & $\begin{array}{c}\text { Average } \\
\text { Growth Rate } \\
(\%)\end{array}$ \\
\hline Power Generation Real Potential & 25397 & 28612 & 31949 & 35152 & 38622 & 10 \\
\hline Thermal Power Generation Real Potential & 22737 & 24631 & 26812 & 29450 & 31847 & 7.7 \\
\hline \begin{tabular}{l} 
Hydroel Power generation Real Potential \\
\hline
\end{tabular} & 2637 & 3920 & 5036 & 5551 & 6574 & 26.9 \\
\hline $\begin{array}{l}\text { Renewable Power Generation Real } \\
\text { Potential }\end{array}$ & 23 & 61 & 101 & 151 & 201 & 78.8 \\
\hline
\end{tabular}

1. How does renewable energy help to replace conventional energy? First, with time, people have more incomes and demand more convenient forms of energy. These energy systems require investment and management. Second it is desirable to switch to better energy forms.

2. How renewable energy can claim higher share of the conventional energy market? Limited availability of fossil fuels and ever increasing environmental concerns would enhance the market share of the renewable energy.

3. What are the environmental concerns both in terms of local and global scale, which would make renewable energy preferable? What opportunities do they offer?

4. Over the years, subsidies have made conventional fuels favorable. Moreover, general population has got used to receiving subsidies in the energy sector.

5. Urban areas need energy on a large scale. Their desire for reliability $(24$ hours availability) is of extreme importance.

6. The present cost structure is not favorable to renewable energy. If all the external cost is accounted for such as environmental costs,

health impacts, etc., some of the renewable energy sources may be advantageous in certain cases.
Now, let us discuss the new contexts in which we have to examine renewable energy, and investigate factors that determine choices for the type of energy system.

\section{Factors that determine choices for energy system}

What factors are considered while selecting an energy system? Some criteria are illustrated below.

Technology: This, include factors such as Scale of Technology (e.g., wind power or nuclear), Efficiency, Locked-up Infrastructure, Product Designs, and Standards.

Costs: Questions such as Who pays?, Who finances?, What are the Interest Rates, Capital Costs, Economic Conditions, Taxes \& Subsidies and Relative Prices of Energy Forms?

Accessibility: Reliability, Infrastructure, Competitiveness, Total Potential, Inadequate Supply, Storage or Hybrid System.

Environment: Pollution, Climate Change, Proximity of Pollution to People, Health and Welfare Concerns, Environmental Impact on humans, property and all living things including plants, animals and agriculture.

Politics: War, Sanctions, Subsidy and Regulation.

Demographic: Life Style, Urban-Rural, Family Size, Age Profile and Personal Values.

Convenience: Time needed Familiarity, Habit and Pleasure.

Safey : Risk Perception, Potential Catastrophe, Sustainability, Renew ability, Future Generation. 


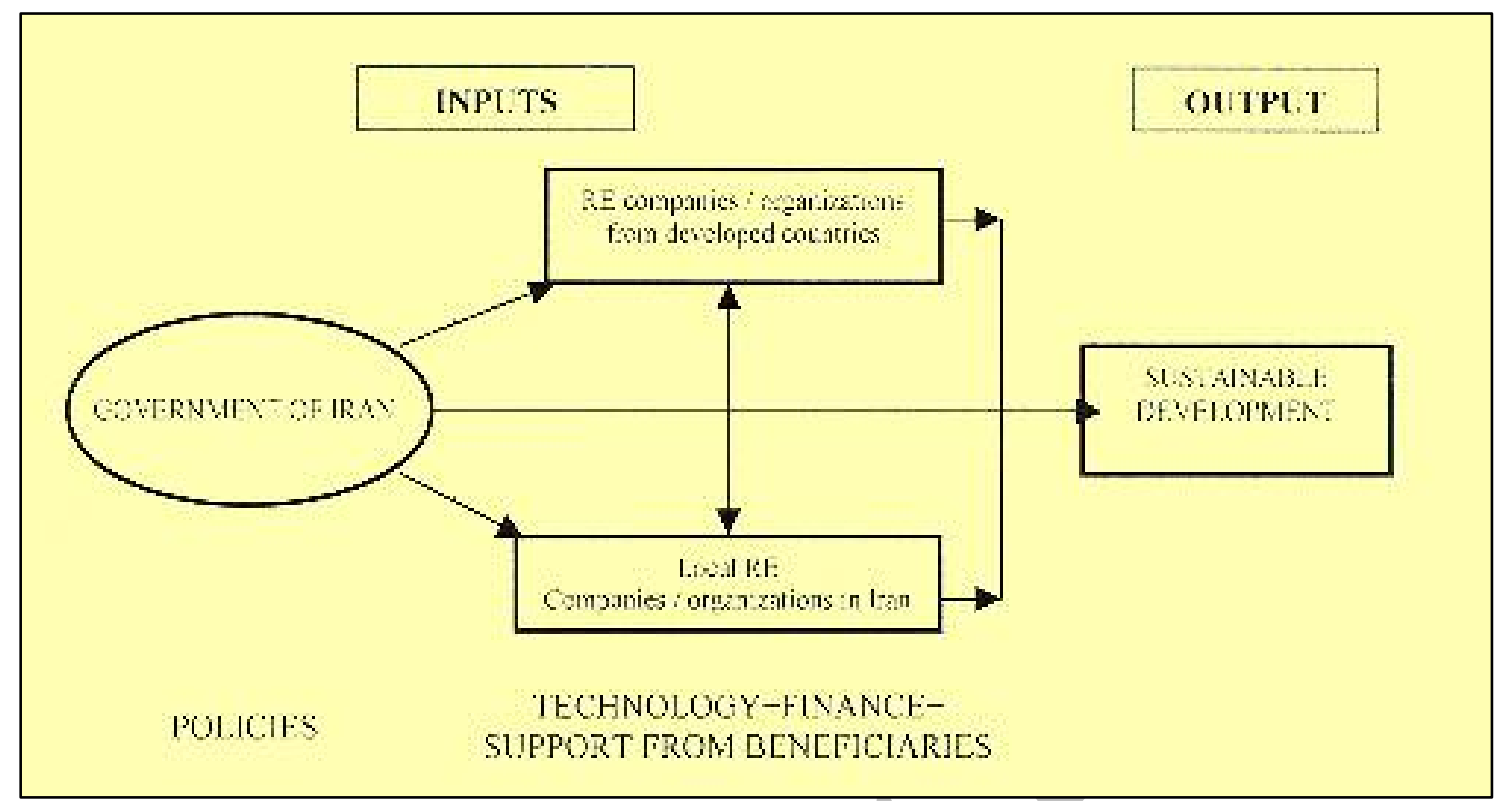

Figure 10: International collaborative business venture model for implementation of RE projects in Iran

Information: Media, Education and Marketing.

\section{Challenges in promotion of RETs in Iran}

The Islamic Republic of Iran lacks policy frameworks that stipulate provision of energy for sustainable development. This poses a great challenge to promote RETs in the country. Appropriate policies are required to successfully implement RETs. Although policy directives have been issued in Iran, stakeholders have not been advised on how to implement them as strategies and long-term policies, i.e., implementation guidelines are lacking. The contribution of RE to the total energy mix is still small, due to lack of knowledge about their potential and insufficient social and environmental policies and programs to encourage their use / implementation. Iran has found it difficult to implement the existing policies and enforce the laws due to lack of infrastructure. The diffusion of RETs has been hampered by lack of training, maintenance and capacity to purchase the technology. Majority of governments in developing nations rely on bilateral or multilateral funding to support RE activities. The external financial aid is not guaranteed and is sometimes tied to meeting donors' conditions, which vary from country to country. The policies that require more attention are those that restrict dissemination of
RETs. The present policies in Iran have serious shortcomings as they lack provisions on standards to ensure quality in the provision of energy. The techno-economic boundary conditions, lack of infrastructure, capital and the tradition of technical standards, represent severe restrictions to rapid expansion of RETs. There has been a tendency by policy makers to compare RE with conventional sources of energy in terms of amount of energy generated. These collective conditions and restraints have made the Islamic Republic of Iran unable to implement the RETs.

\section{Policy options}

The philosophy behind any energy related policy change should be to improve the living standards of the rural and urban inhabitants. Policies should make RETs people orientated, i.e. policies that involve or take into consideration socio-economic needs and cultural background of the beneficiaries in its implementation are preferred. Incorporating the local people into new RE projects is part of the solution to the problem. A successful RE program must be based on the wishes and needs of those people who will use it, and must be driven by their demand for services (light, water pumping, etc.) rather than simply focusing on providing energy technologies (Magoha, 2001).

With increasing problems of accessing external financial aid, the government of Iran 
should not rely on donor support to fund RE projects instead, devise or look for other ways to get funds for RE programs. In order to move forward, formulations of strategies that stimulate development of RE markets are required. The governments of developing countries can encourage the development of RETs by creating legal and fiscal instrument, which promote RE development, contribute financial resources such as direct funding or subsidies, and encourage partnerships between local industry and RE companies in developed countries.

\section{International collaboration}

The objective of setting up business partnerships between local industries in Iran and RE companies in developed countries is to rationalize the management of product quality, by reducing the use of sub-standard equipment. In order to sustain the development of RE projects the issues must be approached in a multi-stakeholder approach in decision making and management of the RE projects.

The objective of the RE projects should be to build partnerships with stakeholders through a process of mutual learning; familiarizing people in the country with new technologies and practices; and organizing seminars and workshops to discuss the successes and failures of these technologies and practices. Various partners (Figure 10) can either fund the initiative in kind or in cash. The advantage of partnerships will offer comprehensive project capabilities and allow partners to work closely together to bring RE to the potential beneficiaries for sustainable development. The partnership expertise should include assistance in development of technical, financial and administrative models.

The extensive experience that the international institutions have accumulated can be passed on to upcoming RE businesses in Iran. The funds allocated for implementation of RE systems can be optimized by concentrating on those applications for which economic advantage is plausible and which are socially and ecologically compatible. Technologies related to RE sources are specifically involved with transfer problems, because they are very specific to local situation and environment. Therefore, there is a need for clear definition of the roles of different parties involved in partnership.

\section{Role of RE companies/ Organizations in Iran}

- Provide bulk of initial capital in the form of loan to fund RE projects. The costs include, provision of hardware and technical knowledge for setting up, implementation and running of the projects.

- Adaptation of the technology to the local conditions. Ensuring that systems are well designed and installed using quality components.

- Supervise RE projects' construction.

- Train local personnel in all aspects of RE technology management to a self-sustaining level. To ensure the success of the RE program, adequate ongoing service and maintenance is very important. This entails organizing training program on manufacture, assembly, financing, installation, maintenance and use of the RE systems.

Role of the Iran government in international collaboration

To be responsible and accountable for providing a clear line of communication between the partners involved in a collaborative business venture.

- Ensuring an open and participatory relationship with the partners at all times, together with maintaining a structure and involvement of partners that is unambiguous.

- Ensuring that all administrative issues pertinent to the smooth running of $\mathrm{RE}$ projects are in place and maintained.

- Ensuring that there is a cohesive approach to RE project implementation and the required infrastructure in place to support the best practice to flourish and the poor practice to be eliminated.

- Standardization of technology i.e., ensuring that technology transfer is optimized with respect to local production costs (labor, capital, energy and materials), local needs, local regulations and laws.

- Provide security and act as a guarantor for any financial loan advanced to local companies / organizations.

- Provide guidelines for loan recovery scheme. The loan repayment scheme should be agreeable to all parties involved in the partnership.

- Provide legal framework for regulating monopolistic control and restrictive practices that hinder RE systems development. 
Role of local business companies / organizations in Iran

- Provide a portion of agreed initial capital (appropriate financial commitment required) for RE project in exchange for the partnership effort.

- Mobilize all communities to support RE projects in kind or cash. With the proper level of involvement and participatory ownership of RE projects by people themselves, it can be a huge success.

- Administer the future management and maintenance of RE projects.

The proposed international collaborative business venture model for RE project implementation will work with the following assumptions in place:

- Finance is available to implement RE projects.

- The supporting role of the government in $\mathrm{RE}$ projects is corruption free.

- Local communities support RE projects.

\section{Interest groups}

The inadequacy of current policies could be addressed by involving various interest groups in RE development plans. Community leaders and NGOs should be instrumental in initiating programs to boost the use of RETs, including convening leaders' meetings to work out plans for promoting RETs. However, these efforts require encouragement by governments and a commitment by communities themselves. Cultural practices that hinder promotion of RE are issues that can only be addressed through a larger framework. People must define their needs, and the imposition of foreign inappropriate technologies without involving the local people, should be discouraged.

Global environmental concerns: Opportunities for Iran

Climate Change is an expected phenomenon due to the emissions of green house gases mainly from burning of fossil fuels, coal, oil and gas. Renewable energy offers zero-GHG-emissions alternative.

The sixth meeting of the Conference of Parties (COP-6) was held in the Hague. The parties were countries that agreed on the Framework Convention on Climate Change (FCCC) at Rio in 1992. Thus the COP negotiations deal with the future of our domestic energy and its policies. In the climate change debate it is also pointed out that unsustainable consumption patterns of the rich countries account for $70 \%$ of fossil fuels. This was recognized in FCCC and a differentiated responsibility for different countries was accepted. Therefore, the convention offered several benefits to the Developing Countries (DCs) such as access to global environment facility to fund their projects on renewable energy; presents technology transfer and costs of capacity building, reporting and country studies. This is a good opportunity for Iran.

Subsequently, the Clean Development Mechanism (CDM) was proposed in the Kyoto Protocol. This can mobilize private investment in the developing countries (DCs) for more efficient use of fossil fuels and therefore cleaner development by bringing much needed capital and new technology. In return, the investors would claim some emission reductions for their countries. Thus CDM offers developing countries finance and technology. Since the cost of reducing emissions is much lower in developing countries compared to Industrialized Countries (ICs), the latter would provide incentive to appropriate technology and finance (UNDP, 1997).

Technology Transfer (TT) promised in the FCCC at Rio could now be linked with CDM so as to ensure wider adaption of the technologies beyond the CDM project. That is, the "CDM project" should have a programmatic context of a long-term nature.

Another way to obtain financial assistance and another opportunity for Iran is through the Global Environment Facility (GEF), which encourages fossil fuel substitution and promotion of renewable energy.

\section{Conclusion}

Lack of finances, poor installation and lack of maintenance are the major hindrances to the ongoing adoption of RETs in our country.

Any co-operation between international and local institutions is bound to produce productive results because international institutions have developed proven expertise in various RETs. They have also built an enormous level of experience in dealing with $\mathrm{RE}$ financing and implementation. The international institutions have ISO 9001 and ISO 14000 registrations that assure the quality 
and environmental responsibility that the Islamic Republic of Iran requires.

The government of Iran could put in place programs that would complement and strengthen RE enterprises by initiating internal reforms that would involve private sector participation. Therefore, RETs offer huge opportunities for social and economic development of Iran. Another critical aspect is the integration of RE courses into a regular training curriculum to tertiary and higher educational institutions at the local, regional and national level within Iran. So Iran needs radical changes in energy sector policies in order to move to harmoniously joint thinking, policymaking and action. The biggest change required is to place environmental objectives at the top of global, national, and personal priorities. This shift definitively does not mean ignoring country's basic needs satisfaction, or its economic and social advancement. But satisfaction of Iran's objectives must be made compatible with environmental goals. This means far greater transfers of financial resources, technology and know-how from industrialized countries to developing ones for environmentally friendly progress.

\section{References}

Center for Renewable Energy Development (CRED), Power Generation in Iran, Ministry of Energy, Islamic Republic of Iran, 2002

Iranian Atomic Energy Agency (IAEA), Renewable Energy Sources, Islamic Republic of Iran, 2000

Iinstitue for International Energy Studies (IIES), Iran Energy Report, Islamic Republic of Iran, 2001

Magoha, P.W., Wind power Industry: Issues in Development and Implementation, Proceedings of ISES Solar Congress, 2001, 25th-30th Nov. 2001, Adelaide, Australia, 2001

Ministry of Energy, Energy Year Book, 1998

United Nations Development Program (UNDP), Energy after Rio, United Nations of America 